\title{
Wpływ uprawiania turystyki na kształtowanie hierarchii wartości i aspiracji życiowych podkarpackiej młodzieży szkół ponadgimnazjalnych
}

The Impact of Practising Tourism for the Forming of a Hierarchy of Values and Life Aspirations of Secondary Schools Teenagers in the Podkarpackie Province

\footnotetext{
ABSTRAKT

Gwałtowne zmiany społeczne i ekonomiczne oraz proces globalizacji niosq wiele zagrożeń dla zdrowia i rozwoju młodzieży. Wiq̨żą się one między innymi ze zmianq aspiracji młodych ludzi, przy jednoczesnym ujawnianiu się postaw konsumpcyjnych. Jest oczywiste i dowiedzione, że aspiracje sq kształtowane poprzez wartości, którymi człowiek kieruje się we własnym życiu. Wartości aprobowane przez człowieka tworza pewnq hierarchię, natomiast pod wpływem hierarchii wartości kształtuje się odpowiadajqca jej hierarchia aspiracji. Dlatego też uwzględnianie wartości w badaniach aspiracji życiowych młodzieży jest bardzo istotne. Wiedza $\circ$ zmianach zachodzqcych $w$ aspiracjach życiowych młodzieży jest niezbędna do podjęcia skutecznych działań w procesie dydaktyczno-wychowawczym oraz socjalizacyj-

SLOWA KLUCZOWE młodzież, hierarchia wartości, aspiracje życiowe, turystyka, Podkarpacie

KEYWORDS

youth, hierarchy of values, life aspirations, tourism, Podkarpackie province

SPI Vol. 19, 2016/1 ISSN 2450-5358 e-ISSN 2450-5366 DOI: 10.12775/SPI.2016.1.010 
nym. Może być także przydatna w organizowaniu i kierowaniu różnymi formami akływności podejmowanymi przez młodych ludzi. Takq aktywnościq, o dowiedzionych walorach dydakłyczno-wychowawczych, jest bezsprzecznie turystyka. Jak wskazuja znawcy tematu, turystyka może być czynnikiem stymulowania „alternatywnego stylu życia”, czynnikiem zmiany postaw w kierunku poszukiwania prawdy, poznawania świata, poznawania siebie, kształtowania wrażliwości emocjonalnej, ponieważ z jednej strony jest zależna od systemu wartości, a z drugiej - jest także nośnikiem określonych wartości.

Celem niniejszego opracowania była próba diagnozy wpływu uprawiania turystyki (aktywności turystycznej) na kształtowanie hierarchii wartości, jakimi młodzi ludzie kieruja się w swoim życiu poprzez ukazanie różnic pomiędzy uczniami o różnym poziomie aktywności turystycznej.

\section{ABSTRACT}

The rapid social and economic changes and the process of globalization are bringing a lot of threats to the health and growth of young people. They are connected, among others, with a change of aspiration of young people, while disclosing their consumer attitudes. It is obvious and proven, that life aspiration is being shaped through values, by which the man is guided in the own life. Values approved by the man are creating some form of hierarchy, while under the influence of the hierarchy of values it is shaped corresponding hierarchy of aspirations. Therefore, taking into account the value in the study of youth aspirations in life is very important. Knowledge about the changes taking place in the life aspirations of young people is essential to take effective action in the pedagogical and the socialization process. It may also be useful in organizing and managing various forms of activities undertaken by young people. Such an activity, with proven teaching-education advantages, is unquestionably tourism. Experts of the subject proved that the tourism could be a stimulating factor of "alternative lifestyle", a changing factor in attitudes toward the search for truth, knowledge of the world, getting to know oneself, forming of the emotional sensitivity because, on the one hand, tourism depends on the human value system, and on the other hand, it also create specific values.

The main purpose of this study was to diagnose the influence of practising the tourism on the formation of a hierarchy of values, which young people are guided in their lives, by showing the differences between students with different levels of tourist activity. 


\section{Wstęp}

$\mathrm{Na}$ gruncie psychologii i pedagogiki młodzież jest definiowana najczęściej jako kategoria wiekowa jednostek będących w stadium przejściowym między dzieciństwem a dorosłością, zmierzających w toku socjalizacji i rozwoju do osiągnięcia pełnej dojrzałości. Natomiast w naukach społecznych jest definiowana zwykle jako grupa społeczna lub też kategoria społeczno-demograficzna, która dzięki swej młodości i dynamice może stawać się czynnikiem zmiany społecznej i wywierać wpływ na przemiany całego społeczeństwa ${ }^{1}$.

Osoby młode nie mają zobowiązań typowych dla człowieka dorosłego, takich jak praca, dom, rodzina, a jednocześnie są już w znacznym stopniu samodzielne i niezależne. Są spragnione wiedzy o świecie, poszukują odpowiedzi na wiele nurtujących je pytań, kształtując ciągle swój system wartości oraz doskonaląc różnorodne umiejętności²

Jednak gwałtowne zmiany społeczne i ekonomiczne oraz proces globalizacji niosą wiele zagrożeń dla zdrowia i rozwoju młodzieży. Wiążą się one między innymi ze zmianą aspiracji młodych ludzi, przy jednoczesnym ujawnianiu się postaw konsumpcyjnych. W aspiracjach, dążeniach i zachowaniach różnych grup młodzieży można dostrzec przemieszanie się „starych” (tj. narodowych, religijnych czy też regionalnych) i „nowych” (treści przekazów medialnych, mody, nowych trendów kultury popularnej) elementów wartości i wzorów społeczno-kulturowych, w różnych proporcjach, $\mathrm{z}$ tendencją do dominacji nowoczesności ${ }^{3}$.

Jak zauważyli znawcy tematu, obraz młodzieży uzyskiwany w prowadzonych w Polsce od 1989 roku badaniach okazuje się coraz bardziej skomplikowany, a rekonstrukcje świata młodzieży są czasem trudno porównywalne ${ }^{4}$. $\mathrm{Na}$ ich podstawie można jed-

1 Por. B. Galas, Mtodzież, w: Encyklopedia pedagogiczna XXI wieku, t. 3: $M-O$, red. T. Pilch, Warszawa 2007, s. 327.

2 Por. K. Przecławski K., Cztowiek a turystyka. Zarys socjologii turystyki, Kraków 1997, s. 48.

3 Por. M.J. Szymański, Uwarunkowania aktywności dzieci i mtodzieży w zmieniającej się rzeczywistości, w: Aktywność dzieci i mtodzieży, red. S. Guz i in., Warszawa 2008, s. 12.

4 Por. B. Fatyga,J. Sierosławski, Uczniowie i nauczyciele o stylach życia mtodzieży i narkotykach. Raport z badań jakościowych, Warszawa 1999, s. 37. Zob. także: K. Koseła (red.), Mtodym być... Mtodzież szkolna '92, Warszawa 1993; B. Fa- 
nak nakreślić pewne cechy młodego pokolenia, nazywanego m.in. „e-generacją", czyli ludźmi urodzonymi już w epoce Internetu. Są nimi: rozpasana konsumpcja, minimalizowanie wysiłku przy maksymalizacji doznań, brak zainteresowań i autorytetów, pasywność, cynizm, pesymizm, pragmatyzm, anarchia, destrukcja i negowanie tradycyjnych wartości ${ }^{5}$.

W świadomości współczesnej młodzieży zachodzą daleko idące zmiany. Przewartościowaniu ulega tradycyjny system wartości, a powszechnie szanowane autorytety często tracą znaczenie. Dlatego też wiedza o zmianach zachodzących $\mathrm{w}$ aspiracjach młodzieży jest niezbędna do podjęcia skutecznych działań w procesie dydaktyczno-wychowawczym oraz socjalizacyjnym. Może być także przydatna w organizowaniu i kierowaniu różnymi formami aktywności podejmowanymi przez młodych ludzi ${ }^{6}$.

Wobec powyższego, wielkiego znaczenia w wyborze stylu życia nabiera obecnie wychowanie młodzieży do rekreacji fizycznej i turystyki. Zdaniem Zofii Żukowskiej, proces ten jest nadzieją na nobilitację wartości tego rodzaju działalności w rozwijającej się cywilizacji oraz czynnikiem kształtowania osobowości i elementem zapobiegania patologiom ${ }^{7}$. Dlatego też na użytek niniejszej pracy, biorąc pod uwage aspekty dydaktyczno-wychowawcze, pod pojęciem turystyki będziemy rozumieć każdy czasowy wyjazd poza miejsce stałego zamieszkania, którego celem i efektem jest wpływ na zmiany w szeroko rozumianym pojęciu osobowości. Zmiany te mogą dotyczyć zarówno sfery intelektualnej, emocjonalnej oraz działaniowej.

tyga, A. Tyszkiewicz (red.), Dzisiejsza mtodzież. Stereotypy i rzeczywistość po 1989 roku, Radom - Warszawa 1997; H. Świda-Zięba, Wartości egzystencjalne mtodzieży lat dziewię́dziesiatych, Warszawa 1995.

5 Por. E. Wysocka, Doświadczanie życia w mtodości-problemy, kryzysy i strategie ich rozwiazywania. Próba opisu strukturalno-funkcjonalnego modelu życia preferowanego przez mtodziezz z perspektywy pedagogiki spotecznej, Katowice 2010, s. 228.

6 Por. A. Zawada, Aspiracje życiowe mtodzieży w środowisku kulturowo zróżnicowanym, Kraków - Katowice 2013, s. 13-15.

7 Por. Z. Żukowska, Aktywna turystyka mtodzieżowa i jej wartości w wychowaniu do zdrowego stylu życia, w: Aksjologia turystyki, red. Z. Dziubiński, Warszawa 2006, s. 279-280.

8 Por. K. Lubański, Pedagogiczny potencjat turystyki, „Zeszyty Naukowe ALMAMER” 2006, nr 3, s. 150. 
Aspiracje życiowe są przedmiotem wielu badań ekspertów z dziedziny socjologii, psychologii czy też pedagogiki. Jednak, jak wskazują różni badacze, jest to zadanie dość skomplikowane, wynikające m.in. z faktu dużego zróżnicowania metod badawczych. Trudności pojawiają się już przy samej próbie interpretacji terminu „aspiracje”. Cechuje go bowiem duża wieloznaczność, gdyż używany bywa zarówno w literaturze naukowej, jak i literaturze pięknej oraz w mowie potocznej’.

$\mathrm{Na}$ potrzeby niniejszego artykułu najistotniejsze są te definicje, które podkreślają silną współzależność aspiracji i wartości. Tak jest w przypadku przywołanej przez Zbigniewa Skornego definicji zaczerpniętej z Wielkiej encyklopedii powwsechnej, mówiącej, że w ujęciu psychologicznym aspiracje to „dążenie do osiągnięcia określonych celów, pragnienie realizacji wyższych wartości, jak różnego rodzaju ideały życiowe, światopoglądowe itp." ${ }^{10}$. Pomocna w tym miejscu jest również definicja Antoniny Kłoskowskiej, podkreślająca, że aspiracje to „kategoria potrzeb świadomych, odnoszących się do przedmiotów i wartości aktualnie nie posiadanych lub takich, które wymagają ciągłego odnawiania, a są uznawane za godne pożądania”. Autorka zwróciła uwagę na fakt, że pojmowanie aspiracji jako potrzeb jest ściśle powiązane $\mathrm{z}$ wartościami ${ }^{11}$.

Jest oczywiste i dowiedzione, że wartości kształtują aspiracje, ponieważ wartości aprobowane przez człowieka tworzą pewną hierarchię, natomiast pod wpływem hierarchii wartości kształtuje się odpowiadająca jej hierarchia aspiracji ${ }^{12}$. Dlatego też na potrzeby niniejszego opracowania aspiracje będziemy rozumieć jako zespół dążeń wyznaczonych przez hierarchię wartości, które jednostka akceptuje i zamierza osiągnąć w bliższej lub dalszej przyszłości. Powyższe powoduje, iż uwzględnianie wartości $\mathrm{w}$ badaniach aspiracji życiowych młodzieży jest bardzo istotne.

9 Por. A. Zawada, Aspiracje życiowe mtodzieży w środowisku kulturowo zróżnicowanym, dz. cyt., s. 49.

10 Z. Skorny, Aspiracje mtodzieży oraz kierujace nimi prawidtowości, Wrocław 1980, s. 16.

11 Por. D. Wiśniewski, Aspiracje mtodzieży ponadgimnazjalnej w kontekście zmian spoteczno-kulturowych, Torun 2012, s. 24.

12 Por. Z. Skorny, Aspiracje mtodzieży oraz kierujace nimi prawidtowości, dz. cyt., s. 116. 
Termin „wartość” (podobnie jak ,aspiracje”) należy do jednych $\mathrm{z}$ najtrudniejszych do zdefiniowania. Wynika to $\mathrm{z}$ faktu, iż w różnych dyscyplinach naukowych znaczenie pojęcia wartości jest coraz większe, a jednocześnie im częściej jest ono stosowane, tym bardziej różnicuje się i rozmywa jego zakres znaczeniowy. Mówiąc o wartościach, dotykamy spraw niezmiernie ważnych dla każdego człowieka: jego aktywności poznawczej, reakcji emocjonalnych, orientacji w różnych sytuacjach - w szczególności dlatego, że dotyczą one sensu życia człowieka ${ }^{13}$.

Choć istnieje wiele definicji wartości, większość z nich jest zgodna co do tego, że wartości są: a) pojęciami lub przekonaniami; b) o pożądanych stanach docelowych lub zachowaniach; c) które wykraczają poza specyficzne sytuacje; d) kierują wyborami i oceną zachowań i zdarzeń oraz e) są uporządkowane według względnej ważności ${ }^{14}$.

Najczęściej jednak wszystko to, co stanowi przedmiot potrzeb, dążeń, postaw i aspiracji człowieka, a co może być przedmiotem materialnym, osobą, instytucją, ideą, rodzajem działania, typem stosunków społecznych itp. - zwykło nazywać się wartościami ${ }^{15}$.

$\mathrm{Na}$ ogół wartości nie funkcjonują w sposób oderwany, pojedynczo, lecz w świadomości ludzi tworzą określone układy, co prowadzi do tworzenia się systemu wartości. Każdy z tych systemów, w założeniu socjologów, ma określoną budowę hierarchiczną, z czego wynika, że jednym wartościom przypisuje się wyższą a innym niższą rangę. W praktyce oznacza to, że istnieje określona hierarchia wartości ${ }^{16}$.

W literaturze przedmiotu istnieje wiele kategorii wartości. Mieczysław Łobocki spośród klasyfikacji wartości wyjątkowo użytecznych dla teorii wychowania wymienia: 1) klasyfikację Eduarda Sprangera, obejmującą sześć grup wartości: teoretyczne, ekono-

13 Por. M.J. Szymański, Mtodzież wobec wartości. Próba diagnozy, Warszawa 2000, s. 9.

14 B. Wojciszke, Cztowiek wśród ludzi. Zarys psychologii spotecznej, Warszawa 2006, s. 178. Por.: S.H. Schwartz, W. Bilsky, Toward a Universal Psychological Structure of Human Values, "Journal of Personality and Social Psychology" 1987, t. 53, s. 550-562; M. Rokeach, The Nature of Human Values, New York 1973.

15 Por. K. Przecławski (red.), Po pracy i nauce. Wzory zachowań mtodzieży w czasie wolnym, Warszawa 1979, s. 79.

16 Por. M.J. Szymański, Mtodzież wobec wartości, dz. cyt., s. 20. 
miczne, estetyczno-artystyczne, społeczne, polityczne, religijne; 2) klasyfikację Ryszarda Jedlińskiego, który wyodrębnia wartości: transcendentne, uniwersalne, estetyczne, poznawcze, moralne, społeczne, witalne, pragmatyczne, prestiżowe i hedonistyczne; 3) klasyfikację Janusza Homplewicza, który wyróżnił wartości transcendentne i naturalne podporządkowane Wartości Nadrzędnej, jaką jest Bóg; 4) klasyfikację Miltona Rokeacha, który wyodrębnił wartości ostateczne, odnoszące się do najważniejszych celów w życiu ludzkim i wartości instrumentalne, dotyczące najogólniejszych sposobów postępowania ${ }^{17}$.

$\mathrm{Na}$ potrzeby niniejszej pracy zastosowano właśnie teorię wartości Rokeacha oraz skonstruowane przez niego narzędzie badawcze, czyli Skalę Wartości (Value Survey) w polskiej adaptacji Piotra Brzozowskiego $^{18}$. Teoria wartości Rokeacha jest częścią ogólniejszej teorii dotyczącej systemu przekonań (belief system). Zdaniem Rokeacha, „wartość jest trwałym przekonaniem, że określony sposób postępowania lub ostateczny stan egzystencji jest osobiście lub społecznie preferowany w stosunku do alternatywnego sposobu postępowania lub ostatecznego stanu egzystencji”. Wartości tworzą system hierarchiczny, dzięki czemu można stwierdzić, że jedne wartości są dla jednostki ważniejsze od innych. Rokeach stwierdził zatem, iż „system wartości jest trwałą organizacją przekonań o preferowanych sposobach postępowania lub ostatecznych stanach egzystencji wzdłuż kontinuum względnej ważności” oraz że ogólna liczba wartości cenionych przez jednostkę jest stosunkowo mała i sprowadza się do kilkudziesięciu ${ }^{19}$.

$\mathrm{Na}$ potrzeby niniejszej pracy postanowiono przyjrzeć się najważniejszym wartościom i kształtowaniu się ich hierarchii wśród badanej populacji uczniów szkół ponadgimnazjalnych z Podkarpacia. Starano się również ukazać związek pomiędzy wartościami cenionymi przez młodzież a aktywnością turystyczną. Dokładniej mówiąc, starano się ukazać wpływ uprawiania turystyki na hierarchię wartości respondentów.

17 Por. M. Łobocki, Teoria wychowania w zarysie, Kraków 2006, s. 99-102.

18 Por. P. Brzozowski, Skala Wartości - polska wersja testu Miltona Rokeacha, w: Techniki kwestionariuszowe w diagnostyce psychologicznej, red. R. Drwal, Lublin 1987, s. 81-122.

19 P. Brzozowski, Wzorcowa hierarchia wartości. Polska, europejska czy uniwersalna?, Lublin 2007, s. 49-50. 
Tematykę wartości w kontekście aktywności turystycznej poruszali m.in.: Józef Lipiec, Krzysztof Przecławski, Zbigniew Krawczyk, Andrzej Matuszyk, Zofia Lubowicz, Krzysztof Lubański, Bożena Alejziak, natomiast o hierarchii wartości oraz aspiracjach młodzieży w stosunku do czasu wolnego pisał Eugeniusz Kosel ${ }^{20}$.

W niniejszym opracowaniu postanowiono zastosować jednak nieco inne podejście badawcze niż prezentowane przez powyższych autorów. Mianowicie w większości prac dominowała tendencja diagnozowania i opisywania wartości, które uczestnik wyjazdu zinternalizował podczas imprezy turystycznej. Różnica polega na tym, że w naszym opracowaniu starano się zbadać wpływ aktywności turystycznej na kształtowanie hierarchii wartości, którymi młodzi ludzie kierują się w swoim życiu. W tym celu najpierw zbadano testem Rokeacha hierarchię wartości młodzieży, a następnie starano się ukazać różnice w strukturze hierarchii wartości między uczniami o różnym poziomie aktywności turystycznej. W tym celu zbadano zależność pomiędzy hierarchią wartości a członkostwem w Szkolnych Kołach Krajoznawczo-Turystycznych (SKKT). W założeniu autora, młodzież działająca w SKKT powinna charakteryzować się wyższym poziomem aktywności turystycznej. Takie ujęcie zagadnienia miało na celu ukazanie wpływu uprawiania turystyki na kształtowanie hierarchii wartości młodzieży. Dokładniej mówiąc, starano się zdiagnozować, czy częstszy udział w wyjazdach turystycznych wpływał na wybór i kształtowanie wartości, którymi młodzież kieruje się w swoim życiu. Było to możliwe ponieważ Skala Wartości Rokeacha obejmuje dwie grupy wartości. Pierwszą tworzy 18 wartości ostatecznych, czyli najważniejszych celów, do których ludzie dążą w życiu. Drugą zaś, 18 wartości instrumentalnych, czyli sposobów zachowania i cech

20 Zob.:J. Lipiec, Filozofia turystyki, w: Nauki o turystyce, red. R. Winiarski, („Studia i Monografie", nr 7), Kraków 2003; K. Przecławski, Humanistyczne podstawy turystyki, Warszawa 1986; Z. Krawczyk, Aksjologiczne uwarunkowania turystyki, w: Antropologia sportu, red.Z. Dziubiński, Warszawa 2002; A. Matuszyk, Pedagogika turystyki jako stosowana aksjologia podrózy, w: Nauki o turystyce, red. R. Winiarski, („Studia i Monografie”, nr 7), Kraków 2003; Z. Lubowicz, Turystyka mtodzieży polskiej lat osiemdziesiatych. Spoteczne funkcje i uwarunkowania, Warszawa 1990; K. Lubański, Turystyka indywidualna a psychologiczne determinanty zachowań, w: Spoteczno-pedagogiczne problemy turystyki, red.J.A. Malinowski, Warszawa 1988; B. Alejziak, Samowychowanie a turystyka, Kraków 2008; E. Kosel, Zasoby czasu wolnego mtodzieży, w: Po pracy i nauce. Wzory zachowań mtodzieży w czasie wolnym, red. K. Przecławski, Warszawa 1979. 
osobowości służących osiąganiu tych stanów. Według koncepcji Rokeacha, to właśnie wartości ostateczne są głównymi wyznacznikami celów, planów życiowych oraz długotrwałych działań, zaś środki do realizacji tych działań przejawiają się w sposobach działania i określane są jako wartości instrumentalne ${ }^{21}$.

Badanie Skalą Wartości polega na rangowaniu listy wartości ostatecznych, a następnie instrumentalnych. Rangujący kierują się ważnością, jaką mają dla nich poszczególne wartości. Każda z wartości musi otrzymać inną rangę.I tak, najważniejsza dla danej osoby wartość z poszczególnej listy otrzymywała rangę pierwszą (otrzymywała wartość 1 ), natomiast najmniej ważna - rangę osiemnastą (czyli wartość 18).

\section{Materiał i metoda badań}

Badaniami objęto młodzież uczęszczającą do różnych typów szkół ponadgimnazjalnych (liceum ogólnokształcące - LO, technikum - T, zasadnicza szkoła zawodowa - ZSZ) z terenu województwa podkarpackiego. Badania przeprowadzono w następujących miastach: 1) miasta do 20 tys. mieszkańców - Brzozów, Sieniawa, Ropczyce; 2) miasta do 50 tys. mieszkańców -Jarosław, Sanok, Dębica; 3) miasta do 100 tys. mieszkańców - Przemyśl, Krosno; 4) miasto do 500 tys. mieszkańców - Rzeszów. Badania główne przeprowadzono w latach 2010-2011. Łącznie wzięło w nich udział ponad tysiąc respondentów. Następnie, po weryfikacji kwestionariuszy do analizy zakwalifikowano kwestionariusze 983 uczniów. W tej liczbie znalazło się 508 kobiet (51,68\%) i 475 mężczyzn (48,32\%); 457 uczniów liceów ogólnokształcących (46,39\%), 406 uczniów techników (41,30\%) oraz 120 uczniów zasadniczych szkół zawodowych (12,21\%).

Spośród badanych uczniów możemy wyróżnić dwie grupy. Pierwszą stanowiła młodzież należąca do Szkolnych Kół Krajoznawczo-Turystycznych, drugą zaś grupę stanowili ci, którzy nie należeli do tego typu organizacji. Taki podział badanych miał na celu ukazanie różnic $\mathrm{w}$ hierarchii wartości oraz aspiracjach życiowych pomiędzy osobami o różnych poziomach aktywności turystycznej oraz świadomości i zaawansowania turystycznego.

21 Por. P. Brzozowski, Skala Wartości - polska wersja testu Miltona Rokeacha, dz. cyt. 81-122. 
Metodą badań zastosowaną w niniejszej pracy był sondaż diagnostyczny, natomiast spośród technik badawczych wykorzystano technikę ankietowania. Wykorzystano także narzędzie badawcze konstrukcji własnej (Kwestionariusz Badania Aktywności Turystycznej Młodzieży), za pomocą którego zdiagnozowano poziom aktywności turystycznej oraz standaryzowane narzędzie badawcze w postaci Skali Wartości (Value Survey) Rokeacha w polskiej adaptacji Brzozowskiego. Polska wersja Skali Wartości posiada dwie podskale, obejmujące po 18 wartości każda:

I. Skala wartości ostatecznych: 1) bezpieczeństwo narodowe (zabezpieczenie przed napaścią); 2) bezpieczeństwo rodziny (troska o najbliższych); 3) dojrzata mitość (bliskość seksualna i duchowa); 4) dostatnie życie (dobrobyt); 5) madrość (dojrzałe rozumienie życia); 6) poczucie dokonania (wniesienie trwałego wkładu); 7) poczucie wtasnej godności (samopoważanie); 8) pokój na świecie (świat wolny od wojen i konfliktów); 9) prawdziwa przyjaźn (bliskie koleżeństwo); 10) przyjemności (miłe uczucie, brak nadmiernego pośpiechu);11) równowaga wewnętrzna (brak konfliktów wewnętrznych); 12) równość (braterstwo, jednakowe szanse dla wszystkich);13) szczęście (radość,zadowolenie);14) świat piękna (piękno natury, sztuki); 15) uznanie spoteczne (poważanie, podziw); 16) wolność (niezależność osobista, wolność wyboru); 17) zbawienie (zbawienie duszy, życie wieczne); 18) życie petne wrażeń (podniecające, aktywne).

II.Skala wartości instrumentalnych: 1) ambitny (pracowity, z inspiracją); 2) czysty (zadbany, schludny); 3) intelektualista (inteligentny, myślący); 4) kochajacy (czuły, delikatny); 5) logiczny (konsekwentny, rozumny); 6) niezależny (niepodporządkowany nikomu, samodzielny); 7) obdarzony wyobraźniq (śmiały, twórczy); 8) odpowiedzialny (niezawodny, rzetelny); 9) odważny (broniący swoich przekonań); 10) opanowany (powściągliwy); 11) o szerokich horyzontach (o otwartym umyśle); 12) pogodny (wesoły, niefrasobliwy); 13) pomocny (niosący pomoc); 14) postuszny (wypełniający polecenia, pełen szacunku); 15) uczciwy (niezdolny do oszustwa, szczery, prawdomówny); 16) uprzejmy (życzliwy, grzeczny wobec innych); 17) uzdolniony (o dużych umiejętnościach); 18) wybaczajacy (gotowy do wybaczenia innym).

Brzozowski za Rokeachem podzielił metodą kompetentnych sędziów wartości ostateczne na „osobiste" i „społeczne”, natomiast wartości instrumentalne na „moralne” $i$,kompetencyjne”. I tak, 1) do grupy wartości społecznych zaliczono: bezpieczeństwo narodowe, pokój na świecie i równość; 2) do wartości osobistych zaliczono: bezpieczeństwo 
rodziny, dojrzałą miłość, dostatnie życie, mądrość, poczucie własnej godności, prawdziwą przyjaźń, przyjemności, równowagę wewnętrzną, szczęście, zbawienie, życie pełne wrażeń; 3) do grupy wartości społeczno-osobistych weszły: poczucie dokonania, świat piękna, uznanie społeczne, wolność; 4) grupę wartości moralnych stanowią: kochający, odpowiedzialny, pomocny, posłuszny, uczciwy, uprzejmy, wybaczający; 5) w skład grupy wartości kompetencyjnych weszły: ambitny, intelektualista, logiczny, obdarzony wyobraźnią, o szerokich horyzontach, uzdolniony; 6) na grupę wartości moralno-kompetencyjnych składają się: czysty, niezależny, odważny, opanowany, pogodny ${ }^{22}$.

W niniejszym opracowaniu powyższym grupom wartości przypisano odpowiadające im grupy aspiracji zaproponowane przez Skornego, który zauważył, że „aspiracje są wskaźnikami odpowiadających im wartości”. I tak, wartościom osobistym i kompetencyjnym przypisano aspiracje osobiste, których realizacja przynosi określone korzyści i zyski dla danej osoby. Do aspiracji osobistych zaliczymy aspiracje rodzinne, ekonomiczno-materialne (bytowe), aspiracje edukacyjno-zawodowe, rekreacyjne. Natomiast do wartości społecznych i moralnych zaliczono aspiracje społeczne, wymagające nawiązywania kontaktów interpersonalnych oraz dotyczące form aktywności przynoszących korzyści określonym osobom lub grupom społecznym. Do aspiracji społecznych można zaliczyć aspiracje kierownicze, towarzyskie, prestiżu społecznego oraz aspiracje prospołeczne ${ }^{23}$.

\section{Wyniki badań}

Wyniki badań zamieszczono w poniższych tabelach. Analiza wyników badań zawartych w tabeli 1 oraz tabeli 2 pozwoliła na określenie poziomu aktywności turystycznej młodzieży oraz jej charakterystykę przez pryzmat przynależności do szkolnych kół o profilu turystycznym i krajoznawczym (SKKT). Okazało się, że przynależność do SKKT miała istotnie znaczenie dla poziomu aktywność turystycznej respondentów (chi^2=14,873, C=0,123, p=0,000). Znakomita większość, bo aż 92,27\%, młodzieży z SKKT wyjeżdżała poza

22 Por. P. Brzozowski, Skala Wartości - polska wersja testu Miltona Rokeacha, dz. cyt., s. 81-122.

23 Por. Z. Skorny, Aspiracje mtodzieży oraz kierujace nimi prawidtowości, dz. cyt., s. 39-54. 
miejsce swojego zamieszkania, a pozostałe 7,73\% badanych nie wyjechało nigdzie w 2010 roku. Młodzież korzystała głównie z wyjazdów krajowych, zarówno tych krótkoterminowych, jak i długoterminowych. Przy czym przynależność do kół miała istotne znaczenie przy wyjazdach krajowych na 2-4 dni ( chi^$\left.^{\wedge} 2=32,706, C=0,179, \mathrm{p}=0,000\right)$ oraz wyjazdach na 5 i więcej dni $\left(\operatorname{chi}^{\wedge} 2=12,642, \mathrm{C}=0,113, \mathrm{p}=0,049\right)$. Wyniki badań zawarte $\mathrm{w}$ obu tabelach pozwoliły pozytywnie zweryfikować pierwszą hipotezę, a mianowicie, że przynależność młodzieży do kół turystyczno-krajoznawczych powoduje wyższy poziom aktywności turystycznej. Możemy zauważyć, bowiem że młodzież z SKKT była bardziej aktywna turystycznie od pozostałych rówieśników (tabela 1). Brała również częściej udział we wszystkich rodzajach proponowanych im wyjazdów turystycznych (tabela 2).

Tabela 1. Aktywność turystyczna w ciqgu ostatniego roku a przynależność do SKKT

\begin{tabular}{|c|c|c|c|c|c|c|}
\hline \multirow{3}{*}{$\begin{array}{l}\text { Uczestnictwo } \\
\text { w wyjeździe } \\
\text { turystycznym }\end{array}$} & \multicolumn{6}{|c|}{ Członkostwo w SKKT } \\
\hline & \multicolumn{2}{|c|}{ Tak } & \multicolumn{2}{|c|}{ Nie } & \multicolumn{2}{|c|}{ Razem } \\
\hline & $\mathbf{N}$ & $\%$ & $\mathbf{N}$ & $\%$ & $\mathbf{N}$ & $\%$ \\
\hline Tak & 227 & 92,27 & 602 & 81,73 & 829 & 84,23 \\
\hline Nie & 19 & 7,73 & 135 & 18,27 & 154 & 15,77 \\
\hline Razem & 246 & 100 & 737 & 100 & 983 & 100 \\
\hline \multicolumn{7}{|c|}{$\operatorname{chi}^{\wedge} 2=14,873, C=0,0123, p=0,000$} \\
\hline
\end{tabular}

Źródło: opracowanie własne

Tabela 2. Rodzaj wyjazdu turystycznego a przynależność do SKKT

\begin{tabular}{|l|c|c|c|c|c|c|}
\hline \multirow{2}{*}{ Rodzaj wyjazdu* } & \multicolumn{5}{|c|}{ Członkostwo w SKKT } \\
\cline { 2 - 8 } & \multicolumn{2}{|c|}{ Tak } & \multicolumn{2}{c|}{ Nie } & \multicolumn{2}{c|}{ Razem } \\
\cline { 2 - 7 } & $\mathbf{N}$ & $\%$ & $\mathbf{N}$ & $\%$ & $\mathbf{N}$ & $\%$ \\
\hline Krajowy na 1 dzień & 161 & 65,67 & 430 & 58,40 & 591 & 60,12 \\
\hline Krajowy na 2-4 dni & 166 & 67,81 & 364 & 49,47 & 530 & 53,81 \\
\hline Krajowy na 5 i więcej dni & 105 & 42,92 & 246 & 33,47 & 351 & 35,71 \\
\hline Zagraniczny na 1 dzień & 28 & 11,59 & 68 & 9,20 & 96 & 9,77 \\
\hline Zagraniczny na 2-4 dni & 39 & 15,88 & 84 & 11,47 & 123 & 12,51 \\
\hline Zagraniczny na 5 i więcej dni & 72 & 29,61 & 170 & 23,07 & 242 & 24,62 \\
\hline
\end{tabular}

* Możliwość wyboru kilku odpowiedzi

Źródło: opracowanie własne 
W tabeli 3 przedstawiono hierarchię wartości ogółu badanej populacji uczniów, zgodną z sumą otrzymanych punktów. Opisany powyżej sposób rangowania spowodował, że w ostatecznym zestawieniu najważniejsza dla ogółu respondentów wartość otrzymała najmniejszą sumę punktów, natomiast wartość najmniej ważna największą sumę punktów. Natomiast zestawienie w tabeli 4 przedstawia ocenę poszczególnych wartości Testem H Kruskalla-Wallisa, który bada różnice $\mathrm{w}$ zakresie zmiennych mierzonych w skalach porządkowych. Do analizy wykorzystano średnie arytmetyczne (śr) i mediany (me). Średnia arytmetyczna wyraża bowiem przeciętny poziom obserwowanej cechy statystycznej w zbiorowości. Mediana natomiast to „wartość", która dzieli zbiór danych „na pół”. Wyznacza ona „wartość” środkową w zbiorze uszeregowanym rosnąco lub malejąco. W poniższej analizie występuje następująca zależność: im niższy poziom średniej i mediany określający daną wartość ostateczną lub instrumentalną, tym jest ona ważniejsza dla respondentów.

Jak można zauważyć, wyniki badań zamieszczonych w obu tabelach obrazują taką samą hierarchię wartości, tzn. wartość, która otrzymała najmniejszą liczbę punktów (tabela 3), miała równocześnie najniższą średnią arytmetyczną (tabela 4); z kolei wartość, której przypisano najwięcej punktów (tabela 3), otrzymała równocześnie najwyższą średnią (tabela 4). Dlatego też analiza wyników badań dotyczących hierarchii wartości badanej populacji zostanie przeprowadzona równocześnie dla obu tabel.

$\mathrm{Z}$ analizy danych wynika, że najważniejszą wartością ostateczną dla ogółu badanych okazało się bezpieczeństwo rodziny (suma punktów 3711 , średnia 3,78, mediana 2,00). Na kolejnych miejscach uplasowały się: szczęście (5338 pkt, śr 5,43, me 5,00); prawdziwa przyjaźn (5706 pkt, śr 5,80, me 5,00); dojrzata mitość (5714 pkt, śr 5,81, me 4,00); mqdrośc (5715 pkt, śr 5,81, me 5,00) oraz wolnoś́ ( 6858 pkt, śr 6,98, me $7,00)$. Najmniej cenionymi przez badanych wartościami ostatecznymi okazały się: świat piękna (10799 pkt, śr 10,99, me 13,00); uznanie spoteczne (10093, śr 10,27, me 12,00); poczucie dokonania (9619 pkt, śr 9,79, me 11,00); bezpieczeństwo narodowe (9480 pkt, śr 9,64, me 11,00) oraz pokój na świecie (9356 pkt, śr 9,52, me 10,00).

Spośród wartości instrumentalnych, a więc sposobów postępowania ułatwiających osiągnięcie powyższych celów ostatecznych, ankietowani uczniowie najbardziej cenili następujące wartości: kochajacy 
(4777 pkt, śr 4,86, me 3,00); uczciwo (5748 pkt, śr 5,84, me 5,00); odpowiedzialny (6179 pkt, śr 6,29, me 5,00); ambitny (6256 pkt, śr 6,37, me 5,00); pomocny (6849 pkt, śr 6,97, me 6,00); czysty (6892 pkt, śr 7,01, me 6,00). Natomiast najniższą rangę ważności przypisano takim wartościom, jak: postuszny (10521 pkt, śr 10,70, me 13,00); o szerokich horyzontach (9708 pkt, śr 9,88, me 11,00); uzdolniony (9624 pkt, śr 9,79, me 11,00); obdarzony wyobraźniq (9296 pkt, śr 9,46, me 11,00) oraz logiczny (8834 pkt, śr 8,99, me 10,00).

Można zatem zauważyć, iż w ogólnym zestawieniu pośród najbardziej cenionych przez młodzież wartości ostatecznych przeważają wartości osobiste. Bezsprzecznie najcenniejszą spośród nich okazało się bezpieczeństwo rodziny. Natomiast w grupie wartości najmniej istotnych dla badanych znalazły się wartości społeczne i społeczno-osobiste. Jedynie wolność jako wartość społeczno-osobista znalazła się na dość wysokim, szóstym miejscu w ogólnej hierarchii wartości podkarpackiej młodzieży. Wśród wartości instrumentalnych nie zanotowano tak wyraźnej różnicy pomiędzy poszczególnymi grupami. Jednak da się zauważyć, iż ważniejszą rangę młodzi przypisali większej liczbie wartości moralnych niż wartości kompetencyjnych. Odnotować należy jednak fakt, że zarówno najważniejsza (kochający), jak i najmniej istotna (postuszny) dla badanych wartość instrumentalna pochodzą z grupy tzw. wartości moralnych. W zestawieniu tym grupa wartości moralno-kompetencyjnych znalazła się w środku ,stawki”.

Stosując inne klasyfikacje i podziały wartości spotykane w literaturze przedmiotu ${ }^{24}$, można podjąć próbę zaliczenia do poszczególnych grup wartości ze skali Rokeacha. Najważniejsze zatem okazały się wartości afiliacyjne, takie jak: bezpieczeństwo rodziny, prawdziwa przyjaźń, dojrzata mitość, kochający, pomocny czy też równość. Wśród wartości samorealizacyjnych wysokie rangi otrzymały: madrość, uczciwy, odważny, poczucie wtasnej godności, z kolei wśród wartości „hedonistycznych" najbardziej preferowane okazały się: szczęście, dostatnie życie, przyjemności i życie petne wrażeń. Istotne okazały się również

${ }^{24}$ Zob. np.: P. Brzozowski, Skala Wartości-polska wersja testu Miltona Rokeacha, dz. cyt.; M.J. Szymański, Mtodzież wobec wartości, dz. cyt.; K. Denek, Wartości jako źródto edukacji, w: Dziecko w świecie wartości, red. B. Dymara, Kraków 2010; M. Łobocki, Teoria wychowania w zarysie, dz. cyt.; J. Lipiec, Świat wartości: wprowadzenie do aksjologii, Kraków 2001. 
wartości świadczące o samokontroli, czyli: odpowiedzialny, czysty, uprzejmy, opanowany. Natomiast mało istotne dla badanej populacji okazały się grupy wartości: prospołecznych (bezpieczeństwo narodowe, pokój na świecie), transcendentnych (zbawienie) czy też estetycznych (swiat piękna).

\begin{tabular}{|l|c|c|l|c|c|}
\hline \multicolumn{2}{|c|}{ Wartości ostateczne } & \multicolumn{2}{c|}{ Wartości instrumentalne } \\
\hline \multicolumn{1}{|c|}{ Nazwa } & $\begin{array}{c}\text { suma } \\
\text { punktów }\end{array}$ & miejsce & nazwa & $\begin{array}{c}\text { suma } \\
\text { punktów }\end{array}$ & miejsce \\
\hline $\begin{array}{l}\text { Bezpieczeństwo } \\
\text { rodziny }\end{array}$ & 3711 & 1 & Kochajqqcy & 4777 & 1 \\
\hline Szczęście & 5338 & 2 & Uczciwy & 5748 & 2 \\
\hline $\begin{array}{l}\text { Prawdziwa } \\
\text { przyjaźń }\end{array}$ & 5706 & 3 & $\begin{array}{l}\text { Odpowie- } \\
\text { dzialny }\end{array}$ & 6179 & 3 \\
\hline Dojrzała miłość & 5714 & 4 & Ambitny & 6256 & 4 \\
\hline Mqqdrość & 5715 & 5 & Pomocny & 6849 & 5 \\
\hline Wolność & 6858 & 6 & Czysty & 6892 & 6 \\
\hline $\begin{array}{l}\text { Poczucie własnej } \\
\text { godności }\end{array}$ & 7357 & 7 & Odważny & 7568 & 7 \\
\hline Dostatnie życie & 7546 & 8 & Pogodny & 7600 & 8 \\
\hline Przyjemności & 8410 & 9 & Uprzejmy & 7663 & 9 \\
\hline Zbawienie & 8707 & 10 & Intelektualista & 8039 & 10 \\
\hline Równość & 8770 & 11 & Niezależny & 8456 & 11 \\
\hline $\begin{array}{l}\text { Równowaga } \\
\text { wewnętrzna }\end{array}$ & 8806 & 12 & Wybaczaiqcy & 8649 & 12 \\
\hline $\begin{array}{l}\text { Życie pełne } \\
\text { wrażeń }\end{array}$ & 9283 & 13 & Opanowany & 8659 & 13 \\
\hline Pokój na świecie & 9356 & 14 & Logiczny & 8834 & 14 \\
\hline $\begin{array}{l}\text { Bezpieczeństwo } \\
\text { narodowe }\end{array}$ & 9480 & 15 & $\begin{array}{l}\text { Obdarzony } \\
\text { wyobraźniq }\end{array}$ & 9296 & 15 \\
\hline $\begin{array}{l}\text { Poczucie } \\
\text { dokonania }\end{array}$ & 9619 & 16 & Uzdolniony & 9624 & 16 \\
\hline Uznanie społeczne & 10093 & 17 & $\begin{array}{l}\text { O szerokich } \\
\text { horyzontach }\end{array}$ & 9708 & 17 \\
\hline Świat piękna & 10799 & 18 & Posłuszny & 10521 & 18 \\
\hline
\end{tabular}

Tabela 3.

Hierarchia wartości badanej populacii zgodnie z sumami punktów (rang) zestawienie ogólne

Źródło: opracowanie własne 
Tabela 4.

Ocena wartości badanej populaci zgodnie ze średnimi i medianami z Testu H Kruskalla-Wallisa (zestawienie ogólne)

\begin{tabular}{|c|c|c|c|c|c|c|c|}
\hline \multicolumn{4}{|c|}{ Wartości ostateczne } & \multicolumn{4}{|c|}{ Wartości instrumentalne } \\
\hline Nazwa & średnia & mediana & miejsce & nazwa & średnia & mediana & miejsce \\
\hline $\begin{array}{l}\text { Bezpie- } \\
\text { czeństwo } \\
\text { narodowe }\end{array}$ & 9,64 & 11,00 & 15 & Ambitny & 6,37 & 5,00 & 4 \\
\hline $\begin{array}{l}\text { Bezpieczeń- } \\
\text { stwo rodziny }\end{array}$ & 3,78 & 2,00 & 1 & Czysty & 7,01 & 6,00 & 6 \\
\hline $\begin{array}{l}\text { Dojrzała } \\
\text { miłość }\end{array}$ & 5,81 & 4,00 & 4 & $\begin{array}{l}\text { Intelektua- } \\
\text { lista }\end{array}$ & 8,18 & 8,00 & 10 \\
\hline $\begin{array}{l}\text { Dostatnie } \\
\text { życie }\end{array}$ & 7,68 & 7,00 & 8 & Kochajacy & 4,86 & 3,00 & 1 \\
\hline Mq̨drość & 5,81 & 5,00 & 5 & Logiczny & 8,99 & 10,00 & 14 \\
\hline $\begin{array}{l}\text { Poczucie } \\
\text { dokonania }\end{array}$ & 9,79 & 11,00 & 16 & Niezależny & 8,60 & 9,00 & 11 \\
\hline $\begin{array}{l}\text { Poczucie } \\
\text { własnei god- } \\
\text { ności }\end{array}$ & 7,48 & 7,00 & 7 & $\begin{array}{l}\text { Obdarzony } \\
\text { wyobraź- } \\
\text { niq̨ }\end{array}$ & 9,46 & 11,00 & 15 \\
\hline $\begin{array}{l}\text { Pokói na } \\
\text { świecie }\end{array}$ & 9,52 & 10,00 & 14 & $\begin{array}{l}\text { Odpowie- } \\
\text { dzialny }\end{array}$ & 6,29 & 5,00 & 3 \\
\hline $\begin{array}{l}\text { Prawdziwa } \\
\text { przyjaźń }\end{array}$ & 5,80 & 5,00 & 3 & Odważny & 7,70 & 7,00 & 7 \\
\hline Przyjemności & 8,56 & 9,00 & 9 & $\begin{array}{l}\text { Opano- } \\
\text { wany }\end{array}$ & 8,81 & 9,00 & 13 \\
\hline $\begin{array}{l}\text { Równowaga } \\
\text { wewnętrzna }\end{array}$ & 8,96 & 10,00 & 12 & $\begin{array}{l}\text { O szerokich } \\
\text { horyzon- } \\
\text { tach }\end{array}$ & 9,88 & 11,00 & 17 \\
\hline Równość & 8,92 & 10,00 & 11 & Pogodny & 7,73 & 8,00 & 8 \\
\hline Szczęście & 5,43 & 5,00 & 2 & Pomocny & 6,97 & 6,00 & 5 \\
\hline Świat piękna & 10,99 & 13,00 & 18 & Posłuszny & 10,70 & 13,00 & 18 \\
\hline $\begin{array}{l}\text { Uznanie } \\
\text { społeczne }\end{array}$ & 10,27 & 12,00 & 17 & Uczciwy & 5,85 & 5,00 & 2 \\
\hline Wolność & 6,98 & 7,00 & 6 & Uprzejmy & 7,80 & 8,00 & 9 \\
\hline Zbawienie & 8,86 & 9,00 & 10 & Uzdolniony & 9,79 & 11,00 & 16 \\
\hline $\begin{array}{l}\text { Życie pełne } \\
\text { wrażeń }\end{array}$ & 9,44 & 10,00 & 13 & $\begin{array}{l}\text { Wybacza- } \\
\text { iq̨cy }\end{array}$ & 8,80 & 9,00 & 12 \\
\hline
\end{tabular}

Źródło: opracowanie własne

Bardzo istotna w kontekście niniejszej pracy jest analiza wyników badań zawartych w tabeli 5, dotyczących różnic w hierarchii wartości pomiędzy członkami szkolnych kół krajoznawczo-turystycznych a uczniami nienależącymi do tego typu organizacji. Okazało się,że dla człon- 
ków SKKT najważniejsze wartości ostateczne stanowiły: bezpieczeństwo rodziny (śr 4,00), szczęscie (śr 5,33), prawdziwa przyjaźn (śr 5,66), mąrość (śr 5,89), dojrzata mitość (śr 6,21) oraz wolność (śr 7,02). Najniżej natomiast oceniono: świat piękna (śr 10,88), uznanie spoteczne (śr 10,64), bezpieczeństwo narodowe (śr 10,28), poczucie dokonania (śr 10,01), zbawienie (śr 9,81) oraz pokój na świecie (śr 9,81). Uczniowie niebędący członkami SKKT za główne cele życiowe uznali te same wartości, nadając im jedynie nieco inne rangi. I tak, hierarchia najważniejszych dla tej grupy wartości ostatecznych przedstawia się następująco: bezpieczeństwo rodziny (śr 3,71), szczęśie (śr 5,44), dojrzata mitość (śr 5,68), madrość (śr 5,79), prawdziwa przyjaźn (śr 5,85) oraz wolność (śr 6,97). Natomiast najniżej cenione okazały się: świat piękna (śr 11,01), uznanie spoteczne (śr 10,16), poczucie dokonania (śr 9,71), życie petne wrażeń (śr 9,47), bezpieczeństwo narodowe (śr 9,43) oraz pokój na świecie (śr 9,42). Zatem najmniej pożądane cele ostateczne były również bardzo zbliżone w obu grupach. Różnica istniała jedynie w ocenie jednej pozycji, tzn. zbawienie, której członkowie SKKT przypisali miejsce 14. Została ona przez uczniów $\mathrm{z}$,opozycyjnej” grupy zastąpiona życiem petnym wrażeń. Druga różnica polegała na rangowaniu poszczególnych wartości. Okazało się również, że wartości instrumentalne, które uzyskały najwyższą preferencję w grupie członków SKKT, stanowiły: kochajacy (śr 5,25), uczciwy (śr 5,90), ambitny (śr 6,47), odpowiedzialny (śr 6,50), czysty (śr 7,33) oraz pomocny (śr 7,38). Grupa uczniów spoza kół turystycznych za najważniejsze drogi postępowania uznała te same wartości, nadając im jedynie nieco inne rangi.

\begin{tabular}{|l|c|c|c|c|c|c|}
\hline & \multicolumn{5}{|c|}{ Członek SKKT } \\
\hline \multirow{2}{*}{$\begin{array}{c}\text { Wartości } \\
\text { ostateczne }\end{array}$} & \multicolumn{3}{|c|}{ Tak } & \multicolumn{3}{c|}{ Nie } \\
\cline { 2 - 7 } & średnia & mediana & miejsce & średnia & mediana & miejsce \\
\hline $\begin{array}{l}\text { Bezpieczeństwo } \\
\text { narodowe }\end{array}$ & 10,28 & 12,00 & 16 & 9,43 & 10,00 & 14 \\
\hline $\begin{array}{l}\text { Bezpieczeństwo } \\
\text { rodziny }\end{array}$ & 4,00 & 2,00 & 1 & 3,71 & 2,00 & 1 \\
\hline Dojrzała miłość & 6,21 & 5,00 & 5 & 5,68 & 4,00 & 3 \\
\hline Dostatnie życie & 8,03 & 8,00 & 8 & 7,56 & 7,00 & 8 \\
\hline Mqqdrość & 5,89 & 5,00 & 4 & 5,79 & 5,00 & 4 \\
\hline $\begin{array}{l}\text { Poczucie doko- } \\
\text { nania }\end{array}$ & 10,01 & 11,00 & 15 & 9,71 & 11,00 & 16 \\
\hline
\end{tabular}

Tabela 5.

Ocena wartości zgodnie ze średnimi i medianami z Testu H Kruskalla-Wallisa (zestawienie ogólne) a przynależność do SKKT 


\begin{tabular}{|c|c|c|c|c|c|c|}
\hline \multirow{3}{*}{$\begin{array}{c}\text { Wartości } \\
\text { ostateczne }\end{array}$} & \multicolumn{6}{|c|}{ Członek SKKT } \\
\hline & \multicolumn{3}{|c|}{ Tak } & \multicolumn{3}{|c|}{ Nie } \\
\hline & średnia & mediana & miejsce & średnia & mediana & miejsce \\
\hline $\begin{array}{l}\text { Poczucie własnej } \\
\text { godności }\end{array}$ & 7,59 & 7,00 & 7 & 7,44 & 7,00 & 7 \\
\hline Pokój na świecie & 9,80 & 10,50 & 13 & 9,42 & 10,00 & 13 \\
\hline $\begin{array}{l}\text { Prawdziwa } \\
\text { przyjaźń }\end{array}$ & 5,66 & 5,00 & 3 & 5,85 & 5,00 & 5 \\
\hline Przyjemności & 8,81 & 9,00 & 10 & 8,46 & 9,00 & 9 \\
\hline $\begin{array}{l}\text { Równowaga } \\
\text { wewnętrzna }\end{array}$ & 9,33 & 10,00 & 12 & 8,83 & 9,00 & 11 \\
\hline Równość & 8,61 & 9,00 & 9 & 9,01 & 10,00 & 12 \\
\hline Szczęście & 5,33 & 5,00 & 2 & 5,44 & 4,00 & 2 \\
\hline Świat piękna & 10,88 & 13,00 & 18 & 11,01 & 13,00 & 18 \\
\hline $\begin{array}{l}\text { Uznanie spo- } \\
\text { łeczne }\end{array}$ & 10,64 & 12,00 & 17 & 10,16 & 12,00 & 17 \\
\hline Wolność & 7,02 & 7,00 & 6 & 6,97 & 7,00 & 6 \\
\hline Zbawienie & 9,81 & 11,00 & 14 & 8,54 & 9,00 & 10 \\
\hline $\begin{array}{l}\text { Życie pełne } \\
\text { wrażeń }\end{array}$ & 9,31 & 10,00 & 11 & 9,47 & 10,00 & 15 \\
\hline \multicolumn{7}{|l|}{$\begin{array}{l}\text { Wartości } \\
\text { instrumentalne }\end{array}$} \\
\hline Ambitny & 6,47 & 6,00 & 3 & 6,34 & 5,00 & 4 \\
\hline Czysty & 7,33 & 6,00 & 5 & 6,91 & 6,00 & 6 \\
\hline Intelektualista & 8,03 & 8,00 & 10 & 8,21 & 8,00 & 10 \\
\hline Kochajqcy & 5,25 & 4,00 & 1 & 4,73 & 3,00 & 1 \\
\hline Logiczny & 8,75 & 9,00 & 11 & 9,04 & 10,00 & 14 \\
\hline Niezależny & 9,27 & 10,00 & 14 & 8,40 & 8,00 & 11 \\
\hline $\begin{array}{l}\text { Obdarzony } \\
\text { wyobraźniq }\end{array}$ & 9,98 & 11,00 & 16 & 9,30 & 10,00 & 15 \\
\hline Odpowiedzialny & 6,50 & 5,00 & 4 & 6,21 & 5,00 & 3 \\
\hline Odważny & 7,77 & 8,00 & 8 & 7,64 & 7,00 & 7 \\
\hline Opanowany & 8,85 & 9,00 & 12 & 8,80 & 10,00 & 13 \\
\hline $\begin{array}{l}\text { O szerokich } \\
\text { horyzontach }\end{array}$ & 9,97 & 11,50 & 15 & 9,84 & 11,00 & 17 \\
\hline Pogodny & 7,82 & 8,00 & 9 & 7,68 & 8,00 & 8 \\
\hline Pomocny & 7,38 & 7,00 & 6 & 6,84 & 6,00 & 5 \\
\hline Posłuszny & 11,04 & 13,00 & 18 & 10,58 & 12,00 & 18 \\
\hline Uczciwy & 5,90 & 5,00 & 2 & 5,82 & 5,00 & 2 \\
\hline Uprzejmy & 7,72 & 8,00 & 7 & 7,81 & 7,00 & 9 \\
\hline Uzdolniony & 10,25 & 11,00 & 17 & 9,65 & 10,00 & 16 \\
\hline Wybaczający & 9,01 & 10,00 & 13 & 8,73 & 9,00 & 12 \\
\hline
\end{tabular}

Źródło: opracowanie własne 
Podsumowując porównanie systemu wartości obu grup, możemy stwierdzić, że są one bardzo podobne. Zarówno członkowie SKKT, jak i ich „niestowarzyszeni” koledzy, dążą do tych samych celów życiowych oraz obierają podobne drogi postępowania. Dominujące okazały się w obu grupach wartości afiliacyjne, hedonistyczne oraz samorealizacyjne, natomiast najmniejszą wagę przywiązywano do wartości prospołecznych, kompetencyjnych oraz estetycznych. Istnieje natomiast nieznaczna różnica $\mathrm{w}$ hierarchii wartości pomiędzy obiema grupami. Można wyróżnić bowiem kilka wartości, których ocena różniła się dość znacznie w obu grupach. Członkowie Szkolnych Kół Krajoznawczo-Turystycznych wyżej ocenili takie wartości, jak: życie petne wrażen, równośc, prawdziwa przyjaźń i logiczny. Nie powinno to dziwić, ponieważ - jak możemy zauważyć - są to wartości, których związek z uprawianiem turystyki jest bardzo bliski. Bowiem życie petne wrażeń opisano w Value Survey jako podniecające i aktywne; równość jako braterstwo; prawdziwa przyjaźn jako bliskie koleżeństwo; logiczny jako konsekwentny, rozumny. Analiza tychże cech wskazuje na bezpośredni związek z uprawianiem turystyki, która wiąże się m.in. z aktywnością, współpracą w grupie, odpowiedzialnością za współtowarzysza eskapady, a więc i bliską przyjaźnią oraz konsekwentnym i rozumnym dążeniem do celu wyprawy turystycznej. Zastanawiające jest natomiast umieszczenie przez członków SKKT wartości świat piękna na ostatnim, tj. 18 miejscu w hierarchii wartości ostatecznych. Okazało się, że ta wartość, opisywana jako piękno natury i sztuki, a więc fundamenty na których oparta jest turystyka i krajoznawstwo, nie była w ogóle doceniana przez badanych. Jest to tym bardziej niepokojące, że nawet uczniowie z SKKT, a więc osoby od których oczekiwać można dużo większej świadomości turystycznej, a jednocześnie większej wrażliwości na piękno otaczającego świata, wykazały się ignorancją emocjonalną w tym zakresie.

\section{Wnioski}

$\mathrm{Na}$ podstawie analizy wyników badań ustalono hierarchię wartości podkarpackiej młodzieży ze szkół ponadgimnazjalnych, a tym samym odpowiadającą jej hierarchię aspiracji. Przeprowadzona analiza wykazała, iż wśród badanej populacji dominują aspiracje osobiste, w tym najważniejsze okazały się aspiracje rodzinne. Nie powinno to 
dziwić, ponieważ troska o najbliższych, bliskość duchowa i seksualna, bliskie koleżeństwo, czułość, a w szczególności poszukiwanie akceptacji wynikające $\mathrm{z}$ potrzeby bezpieczeństwa, to podstawowe założenia afiliacji, a zarazem podstawowe dążenia młodego człowieka. Rodzinę stawia się na czele wszystkich wartości i jej podporządkowuje inne wartości. Jednak znaczenie rodziny możemy tu rozpatrywać w kontekście założenia rodziny własnej. Natomiast budząca się seksualność dorastającej młodzieży sprawia, że na wysokim miejscu w hierarchii sytuuje ona wartości związane ze związkami partnerskimi opartymi na uczuciu.

Ważną grupą wartości, a przez to aspiracji, były wartości hedonistyczne. Znaczenie tych wartości możemy powiązać z liberalizacją życia i coraz większą wolnością obywateli. Można w tym miejscu przytoczyć słowa Mirosława Szymańskiego: „Młodzież ucząca się w szkole ponadgimnazjalnej wie, że warto korzystać z życia i nie zamierza tracić tej możliwości”25.

Najmniej istotne dla badanej populacji okazały się wartości i aspiracje prospołeczne (bezpieczeństwo narodowe, pokój na świecie) i estetyczne (świat piękna). Okazało się, że badana populacja nie jest jeszcze gotowa do zaangażowania się w realizację idei społecznie ważnych. Może to być wynikiem trwającego w naszym kraju przez wiele lat kryzysu zaufania społecznego oraz słabości systemu edukacji, w którym nie wpaja się skutecznie najbardziej elementarnych wartości.

Zdecydowanie na ostatnim miejscu znalazły się wartości estetyczne, których nośnikami mogą być rzeczy, żywe organizmy, osoby, ale także przedmioty sztuki. Młodzi ludzie z Podkarpacia, umieszczając na ostatnim miejscu w hierarchii wartości świat piękna definiowany jako piękno natury i sztuki, okazali się mało wrażliwi na piękno wytworów przyrody oraz piękno dzieł ludzkich. Jest to sytuacja niepokojąca, ponieważ świadczy o lekceważeniu tej grupy wartości $\mathrm{w}$ wychowaniu i edukacji.

Bardzo istotnym porównaniem było zestawienie preferowanych wartości pomiędzy członkami szkolnych kół krajoznawczo-turystycznych a uczniami do nich nienależącymi. Miało to w zamyśle autora ukazać wpływ aktywności turystycznej na kształtowanie hierarchii wartości, a przez to aspiracji młodego pokolenia. Jednak po-

25 M.J. Szymański, Mtodzież wobec wartości, dz. cyt., s. 51. 
równanie obu grup pokazało, że są one bardzo zbliżone. Zarówno członkowie SKKT, jak i pozostali uczniowie, dążą do tych samych celów życiowych oraz obierają podobne drogi postępowania. Dominujące okazały się w obu grupach wartości i aspiracje afiliacyjne, hedonistyczne oraz samorealizacyjne, natomiast najmniejszą wagę przywiązywano do wartości prospołecznych, kompetencyjnych oraz estetycznych. Istnieje natomiast nieznaczna różnica w hierarchii wartości pomiędzy obiema grupami. Wyróżniono kilka wartości, których ocena różniła się dość znacznie w obu grupach. Członkowie szkolnych kół krajoznawczo-turystycznych wyżej ocenili takie wartości, jak: życie petne wrażeń, równość, prawdziwa przyjaźn i logiczny, których analiza wskazuje na bezpośrednie związki z uprawianiem turystyki. Natomiast wartość świat piękna, opisywana jako piękno natury i sztuki, a więc podstawowy walor turystyki i krajoznawstwa, nie była w ogóle doceniana przez badanych. Jest to fakt bardzo niepokojący i dający dużo do myślenia. Podsumowując analizę przeprowadzonych badań i interpretację wyników, nie można niestety potwierdzić znaczącego wpływu uprawiania turystyki przez podkarpacką młodzież szkół ponadgimnazjalnych na kształtowanie jej systemu i hierarchii wartości, a przez to aspiracji życiowych.

\section{BIBLIOGRAFIA}

Alejziak B., Samowychowanie a turystyka, Wydawnictwo „Albis”, Kraków 2008.

Brzozowski P., Skala Wartości-polska wersja testu Miltona Rokeacha, w: Techniki kwestionariuszowe w diagnostyce psychologicznej, red. R. Drwal, Wydawnictwo UMCS, Lublin 1987.

Brzozowski P., Wzorcowa hierarchia wartości. Polska, europejska czy uniwersalna?, Wydawnictwo UMCS, Lublin 2007.

Denek K., Wartości jako źródto edukacji, w: Dziecko w świecie wartości, red. B. Dymara, Oficyna Wydawnicza „Impuls”, Kraków 2010.

Fatyga B., Sierosławski J., Uczniowie i nauczyciele o stylach życia mtodzieży i narkotykach. Raport z badań jakościowych, Instytut Spraw Publicznych, Warszawa 1999.

Fatyga B., Tyszkiewicz A. (red.), Dzisiejsza mtodzież. Stereotypy i rzeczywistość po 1989 roku, Instytut Technologii Eksploatacji, Ministerstwo Edukacji Narodowej, Radom - Warszawa 1997.

Galas B., Mtodzież, w: Encyklopedia pedagogiczna XXI wieku, t. 3: M-O, red. T. Pilch, Wydawnictwo Akademickie „Żak”, Warszawa 2007. 
Kosel E., Zasoby czasu wolnego mtodzieży, w: Po pracy i nauce. Wzory zachowań mtodzieży w czasie wolnym, red. K. Przecławski, Instytut Wydawniczy CRZZ, Warszawa 1979.

Koseła K. (red.), Mtodym być... Mtodzież szkolna '92, CBOS, Warszawa 1993.

Krawczyk Z., Aksjologiczne uwarunkowania turystyki, w: Antropologia sportu, red. Z. Dziubiński, Salezjańska Organizacja Sportowa RP, Warszawa 2002.

Lipiec J., Filozofia turystyki, w: Nauki o turystyce, red. R. Winiarski, („Studia i Monografie”, nr 7), AWF, Kraków 2003.

Lipiec J., Świat wartości: wprowadzenie do aksjologii, „Fall”, Kraków 2001.

Lubański K., Pedagogiczny potencjat turystyki, „Zeszyty Naukowe ALMAMER" 2006, nr 3.

Lubański K., Turystyka indywidualna a psychologiczne determinanty zachowań, w: Spoteczno-pedagogiczne problemy turystyki, red. J.A. Malinowski, Instytut Turystyki, Warszawa 1988.

Lubowicz Z., Turystyka mtodzieży polskiej lat osiemdziesiatych. Spoteczne funkcje i uwarunkowania, Instytut Turystyki, Warszawa 1990.

Łobocki M., Teoria wychowania w zarysie, Oficyna Wydawnicza „Impuls”, Kraków 2006.

Matuszyk A., Pedagogika turystyki jako stosowana aksjologia podróży, w: Nauki o turystyce, red. R. Winiarski, („Studia i Monografie”, nr 7), AWF, Kraków 2003.

Przecławski K., Cztowiek a turystyka. Zarys socjologii turystyki, „Albis”, Kraków 1997.

Przecławski K., Humanistyczne podstawy turystyki, Instytut Turystyki, Warszawa 1986.

Przecławski K. (red.), Po pracy i nauce. Wzory zachowań mtodzieży w czasie wolnym, Instytut Wydawniczy CRZZ, Warszawa 1979.

Rokeach M., The Nature of Human Values, The Free Press, New York 1973.

Schwartz S.H., Bilsky W., Toward a Universal Psychological Structure of Human Values, "Journal of Personality and Social Psychology" 1987, t. 53, s. 550-562.

Skorny Z., Aspiracje mtodzieży oraz kierujące nimi prawidtowości, Zakład Narodowy im. Ossolińskich, Wrocław 1980.

Szymański M.J., Mtodzież wobec wartości. Próba diagnozy, Instytut Badań Edukacyjnych, Warszawa 2000.

Szymański M.J., Uwarunkowania aktywności dzieci i mtodzieży w zmieniajacej się rzeczywistości, w: Aktywność dzieci i mtodzieży, red. S. Guz i in., WSP TWP, Warszawa 2008.

Świda-Zięba H., Wartości egzystencjalne mtodzieży lat dziewięćdziesiątych, ISNS UW, Warszawa 1995.

Wiśniewski D., Aspiracje mtodzieży ponadgimnazjalnej w kontekście zmian spoteczno-kulturowych, Wydawnictwo Adam Marszałek, Toruń 2012. 
Wojciszke B., Cztowiek wśód ludzi. Zarys psychologii spotecznej, Wydawnictwo Naukowe Scholar, Warszawa 2006.

Wysocka E., Doświadczanie życia w mtodości-problemy, kryzysy i strategie ich rozwiązywania. Próba opisu strukturalno-funkcjonalnego modelu życia preferowanego przez mtodzież z perspektywy pedagogiki spotecznej, Wydawnictwo Uniwersytetu Śląskiego, Katowice 2010.

Żukowska Z., Aktywna turystyka mtodzieżowa i jej wartości w wychowaniu do zdrowego stylu życia, w: Aksjologia turystyki, red. Z. Dziubiński, Salezjańska Organizacja Sportowa RP, Warszawa 2006.

\section{ADRES DO KORESPONDENCJI:}

Dr Marcin Warchoła

Państwowa Wyższa Szkoła Techniczno-Ekonomiczna

im. ks. B. Markiewicza w Jarosławiu

e-mail: marcin.warchola@pwste.edu.pl 